
SB 741 Cornell University Library

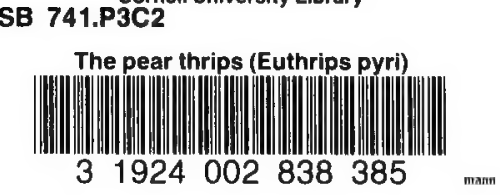


STATE HORTICULTURAL COMMISSION P3C" ELLWOOL' COOPER, Commissioner

\section{THE \\ PEAR THRIPS (Euthrips pyri)}

BY

\section{- DUDLEY MOULTON}

Entomolosist for Santa Clara County, California

ILLUSTRATED WITH ORIGINAL DRAWINGS BY W. S. ATKINSON AND PHOTOGRAPHS BY A. P. HILL

\section{SACRAMENTO}

W. W. SHANNON,

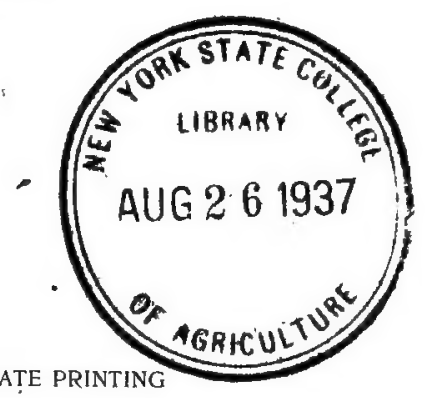

SUPT. STATE PRINTING 


\section{CONTENTS.}

DESCRIPTION OF THE INSECT

PAGE.

OCCURRENCE AND DISTRIBUTION

6

NATURE AND EXTENT OF INJURY

7

LIFE-HISTORY AND HABITS

10

METHODS OF CONTROI,

14

SUMMARY

17 


\section{THE PEAR THRIPS.}

(Euthrips pyri.)

During the months of February, March, and April, if one were to examine closely the branches of many of the fruit trees in the Santa Clara Valley, he would find numerous brown insects, about one twentieth of an inch long, hidden within the buds, blossoms, or leaves, and if these are disturbed by being shaken out over one's hand, they suddenly become active, raise up the tip of the abdomen, and lifting and disentangling their wings, fly away. They are so small and their wings so transparent, that unless one watches very closely they disappear even before one's eyes. Such, in brief, is the thrips pest of our orchards-a rather attractive and for many reasons a very interesting insect.

The pear thrips was described in "Entomological News" for November, 1904, by Miss D. M. Daniel, of the University of California. Her type specimens were taken from pear blossoms near San Leandro, Alameda County, hence the name "pyri," the pear thrips. Miss Daniel's original description is as follows (see Fig. 1):

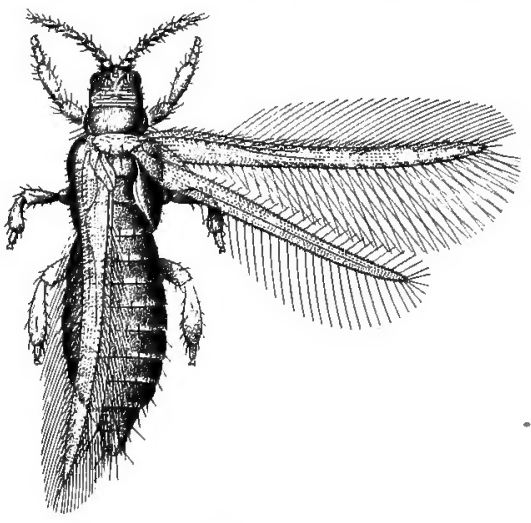

FIG. 1. Pear Thrips, greatly enlarged. (Original.)

Female.-Length, $1.26 \mathrm{~mm}$; width of mesothorax, .32 mm.; general color, dark brown. Head about as long as broad; cheeks convexed; anterior margin broad, acutely angular; back of head transversely wrinkled, and bearing a few minute spines. Eyes medium, black with light borders, rounded or oval in outline, coarsely faceted, hairy. Ocelli yellow, margined inwardly with reddish-brown crescents, widely separated, posterior ones contiguous, with light borders around eyes; one very long, slender spine on each side midway between ocelli. Mouth-cone pointed, tipped with black; maxillary palpi 3-segmented. Antennæ 8-segmented, approximate, slightly over twice the length of head. Length of segments: $33,43,55,52,35,50,8,10$. Antennæe brown, except segment three, which is yellow. Spines pale, conspicuous, special sense organs on segments three and four.

Prothorax longer and wider than head; bears many prominent spines, the one at each anterior angle and the two at each posterior angle are longest. Color, yellowbrown; faintly cross-striated.

Mesothorax approximately as wide as antennæe are long; front angles obtusely rounded; metanotal plate bears four spines close to front edge, middle pair equal in 
size and prominence to those at the angles of prothorax, the others are small; pterothorax yellow-brown, transversely wrinkled.

Wings present, extending slightly beyond abdomen, about twelve times as long as wide, pointed at ends; surface of wings thickly covered with minute brown spines; both longitudinal veins and costa of fore wings thickly set with quite long, brown-colored spines, placed regularly on costa and hind vein; costa has from 29-33 spines, fore vein 12-15, and hind vein 15-16; veins not prominent; costal fringe of fore wings about twice as long as costal spines.

Legs moderately long, scarcely thickened; femora and all except the terminal part of tibia brown; terminal part and tibiæand tarsi yellow, a double row of twelve strong spines on the inner side of hind tibia, several inconspicuous spines on fore and middle pairs.

Abdomen about two and one half times as long as width of mesothorax, cylindrical to eighth segment, then abruptly pointed. Spines on sides and around tip of abdomen dark brown, conspicuous; those on last two segments are long and approximately equal. Color of abdomen dark brown, connective tissue yellow.

\section{OCCURRENCE AND DISTRIBUTION.}

We know now that the pear thrips is not confined to Alameda County, where it was first found, and to the Santa Clara Valley. We have learned, through Prof. C. W. Woodworth of the University of California, that during the present year it has been injuring fruit trees around Vacaville and Suisun and along the Sierra foothills. During a recent trip through the southern part of California, I learned of its presence in Los Angeles County. Other than this we do not know how widespread the pest is, nor where it originated, whether here in California or whether it is an introduced species. The insect may have originated on some of our wild plants, such as the wild plum or cherry, and later as our valleys have developed into large fruit-growing districts, the insect, finding more and better food, may have changed its feeding habits from wild to cultivated plants. This would be a not unnatural change. On the other hand, it may have been imported and here finding conditions farorable without any effective natural insect enemies or fungous diseases, it has spread and developed accordingly.

Euthrips pyri first came particularly to the notice of the Santa Clara County public in February, 1904, when several orchardists noticed that their trees were not coming into blossom in the usual way. The buds appeared blasted, turned brown and fell without opening, and trees which did blossom dropped their petals early. In either case the trees looked much as though a hot blast had passed over them. This, as orchardists remember, had happened in places for several years and the injury had not been explained. Last year an attentive observer actually found certain tiny insects in the blossoms, and the cause of the injury was at once apparent. The insects were brought to the attention of Mr. Ehrhorn, former Horticultural Commissioner of the county, now first deputy State Horticultural Commissioner, who determined them to be thrips. Immediately on learning of the damage 
caused by this "new insect" in the orchard of R. K. Thomas, where it was first observed, many people made special visits to his place to find out what the insect was like, not realizing that by shaking a few blossoms from almost any tree in their own or a neighbor's orchard the dreaded insects could be found.

To those people who are not well acquainted with the general appearance and habits of this group of insects, the pear thrips look very much like those found ordinarily in grasses, flowers, etc.; but on close examination one finds very strong individual characteristics as regards their structure and life habits. The thrips which are commonly found in roses and other flowers are not the destructive forms which injure our fruit trees.

\section{NATURE AND EXTENT OF INJURY.}

It is the adult thrips which first comes to our trees in countless numbers, and which does the great and serious injury.; it is this stage, also, which is most conspicuous and which is best known to orchardists.

The manner in which thrips attack trees is, generally speaking, much the same. They arrive just before or while the buds are opening, and enter the bud, if possible, otherwise they begin to feed on the tip and eventually work their way in. When once inside they attack the tenderest of the flower parts and in many cases reveal a rather. fastidious taste, preferring some particular part, such as the stamen; petal, or pistil.

The mouth parts of thrips project from the lower posterior side of the head and have somewhat the shape of an inverted cone (Fig. 2).

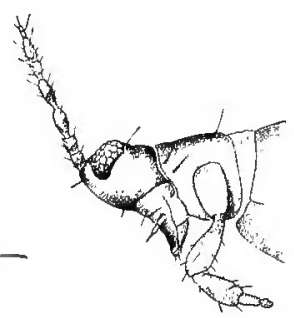

Fig. 2. Month parts of Thrips, greatly enlarged. (Original.) The mouth opening, the rim of which is strongly chitinized and roughened, rasp-like, is in the smaller distal end of the cone, and through it project two stylets or needles. The insect, when feeding, first pierces the plant tissue with the stylets, thus making an opening; then moving the mouth-cone back and forth it rasps and tears the opening larger, and, pushing the tip of the mouth-cone down into this puncture, sucks in the juices of the plant.

The specific injury to blossoms varies in different plants. Trees may be divided into two groups as regards the structure of the blossom bud: (1) in which a single bud produces one blossom, such as the almond, apricot, and peach; and (2) where one bud opens out into a cluster of blossoms, which later produce a cluster of fruit, such as the prune, cherry, pear, and apple. In the development of the bud, the winterprotecting scales are the first to spread, thus permitting the insects to enter at the tip. In the apricot and peach the insect forces its way in 
at the tip and down between the sheath scales and the blossom; it feerls first on the outer side of the blossom, and especially on the very tender blossom stalk in the center at the base; later it feeds on the inner parts of the flower. When the insect is once inside the bud it takes but a comparatively short time to destroy the blossom. Many buds on peach and apricot trees, thus injured, will fall with a slight tapping of the limb.

Many instances can be cited where thrips were especially numerous

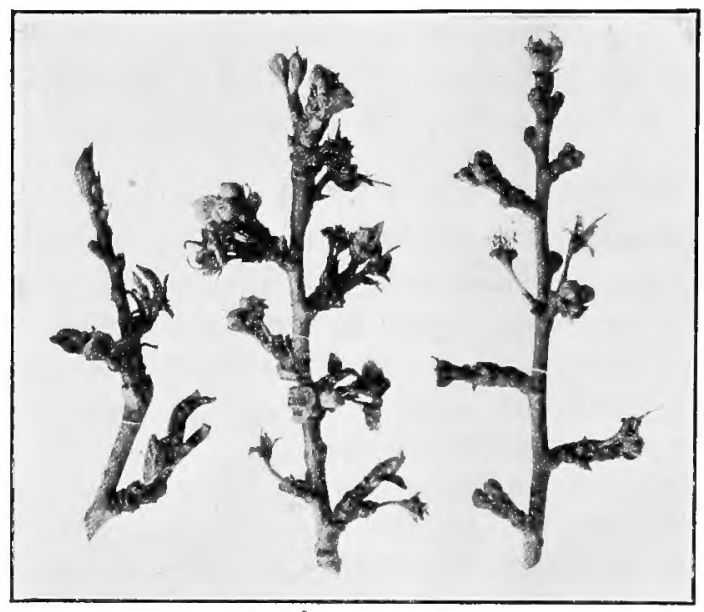

FIg. 3. Imperial Prune branches. Blossons and leaf buds affected. Every blossom on these twigs has been killed. On the two inner branches many of the clusters have fallen. in almond blossoms, yet the trees set and matured a large crop of nuts. The probable explanation of this is that the trees were almost in bloom before the insects arrived in dangerons numbers. The thrips did not get a chance at the newly opening buds, and, after the blossoms had opened, the nature of the insects' feeding was such that no serious injury to the fruit followed. The insects did not at-

tack a vital part of the blossom, but seemed to prefer the inside of the calyx-cup at the base of the stamens, and they did not seem to injure any other part of this particular blossom, although they were often present in very large numbers. Soon after pollination the calyx-cup is sloughed off and the fruit left apparently no worse for the presence of the insects.

Thrips do even more serious injury to blossoms of the second group (prunes, cherries, etc.) than they do to those of the first. The insect enters at the tip of the swelling bud and forces itself down the center of the cluster, injuring each blossom on the inner, contiguous side. When thus affected, natural growth ceases. For a time the untouched outer side of each budlet grows in the natural way, while the injured inner side has ceased growing. The deformity thus produced causes each budlet to turn in toward the center, and all of the cluster eventually fall. The injury done by thrips during this early opening of the bud is by far the most serious. As blossoms develop 
thrips display their preference for certain flower parts; in cherries and prunes, the tips of the petals and the stigma and style are the parts that suffer.

The feeding of thrips in leaf buds and on tender foliage is almost as disastrous as when they attack blossoms. In many cases where trees have suffered injury for three or four days it takes several months for them to again put forth new buds and foliage and to again assume their natural growth, and then often they appear sickly for the entire year. The rapidity with which whole orchards have been injured marks this as one of the worst pests which we have ever had to fight.

The insect is known to feed on the following plants, and it is probable that even this list is not complete: Apricot (several varieties), apple, almond, cherry, fig, grape, pear (Doyenne du Comice and Bartlett preferred), prune

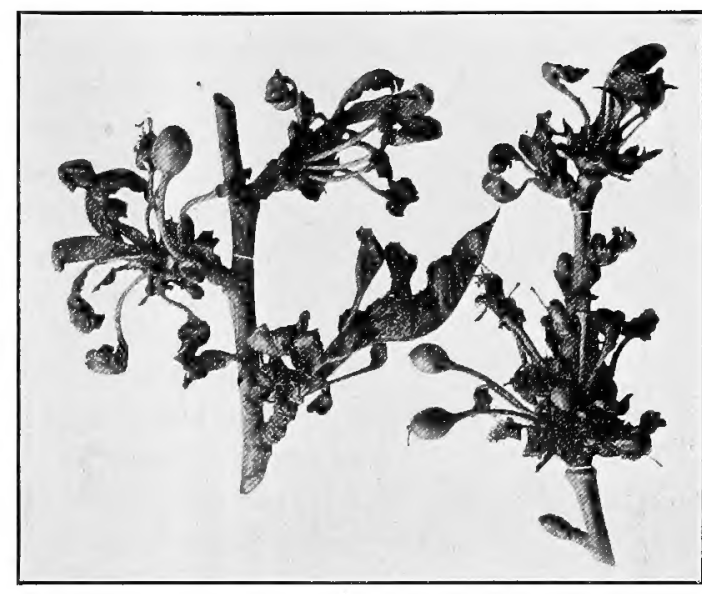

Fig. 4, Black Tartarian cherries, showing dead blossoms, the work of mature thrips; and deformed leaves, the effect of the feeding of young thrips.

(Imperial preferred), plum, walnut (English), and peach (Muir and Clings (Nichols) preferred). As mentioned, the insect gives preference to certain varieties of prunes, peaches, and pears, and of the other fruits all seem to be affected alike. The Imperial prune is especially susceptible to the attacks of thrips. Last year it was generally known that the thrips could absolutely clean an orchard of its fruit. This year, when the insects began to appear, of course every one was alarmed, fearing that wherever a few thrips were present more would appear and all orchardists would suffer the same damage which a few had experienced the year before. This overanxiety was stimulated also by the lack of knowledge on this particular thrips. No one seemed to know where it came from, how many broods there were, how long it would feed, or where it would go at the end of the season.

It is impossible to estimate the loss caused by thrips during the season of 1904, though we know of a number of orchards where the crop was a complete failure. This year, while the injury is very serious, we are again unable even to estimate the loss. The insect is much more widespread, but during the last blossom season there occurred unusu- 
ally heavy driving rains, and we were unable in many cases to determine the amount of injury done by the thrips and the amount caused by the rain, except in those places where injury done by the insects was noticed before the rains came on. The damage, however, will aggregate many thousands of dollars.

\section{LIFE-HISTORY AND HABITS.}

The Egg, the Ovipositor, and the Placing of the Egg.-The egg is beanshaped, is almost transparent, and when seen within the body of the

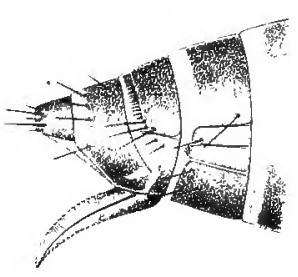
adult female is very large in proportion to the size of the abdomen. It can be seen only with a powerful lens or microscope.

The ovipositor-the organ fitted for cutting an incision in the plant tissue and for conveying eggs from the abdomen of the adult female into this incision-is made up of four distinct Fig. 5. A d bdominal segments plates, each of which has a serrate outer edge,
of thrips, showing ovipositor, greatly enlarged. is pointed, and is operated by powerful muscles (Original.) and plates within the abdomen. (See Fig. 5.)

In placing an egg, the thrips first tears or weakens the plant epidermis by means of the mouth parts, takes a step forward, and, arching the abdomen a little, lowers the ovipositor from its sheath in the last two abdominal segments, almost at right angles with the body, and by operating the tiny saws up and down, she enlarges the opening and cuts à quite deep incision. When this is finished an egg is forced down through the space between the four plates and into the cavity below, underneath the plant epidermis. The operation of making the incision, of depositing a single egg, and of withdrawing the ovipositor requires from four to ten minutes, and has been observed many times. One often finds a branch or a whole tree where almost every female will be depositing eggs at the same time. For depositing eggs, the tiny and very tender stems of blossoms and leaf petioles are preferred, and as the leaves develop the midrib and veins on the lower side of the leaf are chosen and later the tissue of the leaf itself. It has been stated by other observers that the feeding and depositing of eggs go together; indeed, the destructive work of the ovipositor is quite as effective as the injury caused by feeding, for the cutting of numerous incisions into a tiny stem greatly weakens it. We have seen the stems of cherries and prunes so injured in this way that, after the fruit becomes almost half grown, the stem weakens and the fruit falls.

The insect always chooses the tenderest parts of a plant for oviposition, and this with reason. If the tissue is hard there is danger of the ovipositor becoming fastened so that it can not be withdrawn. Also, 
during the development of the egg and the issuing of the larva it is necessary that the tissue be very flexible; the egg must be in close connection with the tree sap and must be kept moist, for the egg-covering is elastic and the embryonic thrips within increases in size quite noticeably before it isEues. The egg stage lasts approximately four days.

As the fully developed eggs are quite large there is space inside of the adult insect's body for but a few at a time---seven or eight. The insect probably places but few eggs during a single day. She feeds for a time and deposits an egg, and then moves to another and still other places; this may be on one or more trees, and thus she spreads her progeny from tree to tree and from place to place wherever she goes. When once set on ovipositing nothing seems to hinder, as we have observed thrips, in the act of placing their eggs at all hours of the day and night and under all conditions of weather. The period of oviposition is of several weeks' duration, or practically all of the life of the adult insect; and when oviposition is finished the life mission of the adult has been fulfilled and death follows. It is interesting to note in this connection that all adult insects which we have observed up to the present time have been females, no males having been found.

Larva, Description and Habits.-The larvæ of the pear thrips, of which we have determined two stages, are tiny, white, soft-bodied, wingless forms, with the customary pair of antennæ, three pairs of legs, and with mouth parts similar to those of the adult, as already described. It is interesting to watch, with the aid of a strong lens, a young thrips issuing from the egg. The tiny speck of an incision in the stem of a blossom or leaf tells us where an egg has been placed, and the enlarging of the egg within, causing a swelling in the plant tissue at the summit of which is the incision, tells us of the new insect about ready to emerge. The first signs of life are apparent when the tiny head with its bright red eyes appears, pushing out of the incision; little by little, and, swaying backward and forward, the larva works itself out until about half of the body is exposed, when first the antennæ, then one by one the pairs of legs, are made free from their resting position against the body. Still swaying backward and forward, with legs and antennæ waving frantically about as if glad of the power of action and eager to get free, the tiny insect works itself out from the egg-covering and the cavity in which the egg was placed, almost to its full length, when it leans forward and eagerly takes hold with its newly formed feet, and with a few final efforts it pulls itself free and walks rapidly away. From four to ten minutes are required for the young insect to thus free itself from the egg. A number of leaves and blossom-stems in which eggs had been placed were brought into the office and closely watched to determine the length of time spent in the egg. In many cases these 
stems would become dry during the four days of confinement, and almost invariably no young thrips issued. The egg seemed to need the moisture for its preservation and development, and the young thrips must have very tender and pliable tissue in order to be able to emerge. The young insect is almost transparent, and when food is taken in the green (chlorophyll) particles can be seen through the borly wall. From the beginning the body growth is very rapid, and a f('w insects are capable of doing great injury, so voracious are they in feeding.

Young thrips feed almost entirely on tender foliage and fruit, ancl their manner of feeding is much the same as that of the adult insect, it

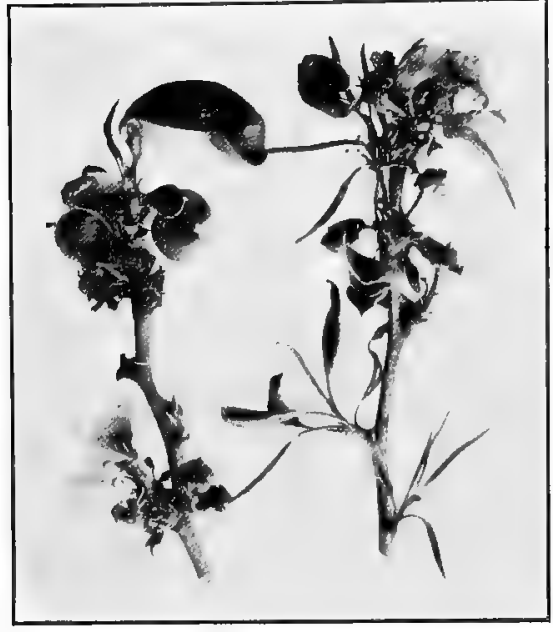

FIG. 6. Bartlett Pear. Dead blossom clusters conspicuous; one late straggling blossom left untouched, the adult thrips having all left the tree. Leaves deformed.

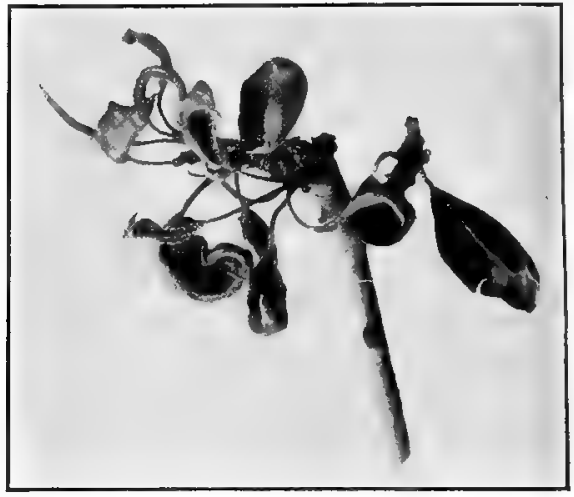

FIG. 7. Pear branch, showing the rolling and the cup-shaped deformities of the leaf; injury caused by the feeding of young thrips.

being a rasping and sucking combination. They usually prefer the tenderest foliage, such as terminal buds, but often, as in the cherry, they attack the under side of leaves near the prominent veins, causing them to become much contorted and ragged, and full of holes.

Young thrips are perfectly helpless creatures and subject to the attacks of other insects, but they seem to be able to protect themselves in a remarkable way. They are commonly secreted in the terminal tips of the branches, but in some cases they seem to take advantage of certain tendencies in the growth of the plant on which they happen to feed. Newly opening pear or apple leaves have a tendency to roll from the sides inward. Young thrips find this inner protected surface a most desirable place for food and shelter, and in feeding, the upper leaf 
surface alone is weakened, which causes the leaf to roll up until eventually it becomes rolled up tight (Fig. 6). In doing this the insects get the tenderest part of the leaf for their food, and also secure protection for themselves. With such shelter no ordinary predaceous insect can reach them. Often on more mature leaves the insects in feeding cause a deadening of the margin and the leaf in its development is forced into an abnormal, cup-shaped growth. This is a very characteristic injury on pear trees (Fig. 7).

The list of food plants of young thrips is larger than during the adult stage. Aside from all the fruit trees mentioned on which the adults feed and also on which the young are to be found, it often happens that the young, by various means, are carried from the original food plant to some other, being blown, for example, from the tree above to a weed beneath. They have no wings and can not fly back to the tree; a few crawl up again, but most of them adapt themselves to the new food plant until fully grown, when they go into the ground with the others. All of our common weeds have thus been found supporting young thrips, although no full-grown insects have been seen feeding and depositing eggs on such plants.

It is the young thrips which injures fruit. especially are affected, although a similar scab is found on cherries, apricots, and pears. Well-set fruit gets to be about the size of a pea before the old blossom is sloughed off, and under cover of this dead blossom, on almost every prune where thrips were present, one or more of the young could be found, ${ }_{\text {FIG. } 8 \text {. Thrips in second }}$ also a small abrasion on the skin of the fruit where larval stage, greatly the insect had been feeding. We have followed this enlarged. (Original.) abrasion of the skin with the thrips present to the mature fruit with its scab. Only the skin of the fruit is injured, and the marking enlarges with the growth of the fruit. The scab was especially marked last year where thrips were found, and it was very prevalent again this year. It must be remarked, however, that something other than thrips has caused much of the scab on prunes during the past year.

During the second larval stage of the young thrips a very decided change takes place. The second larva, like the first, feeds voraciously and after some three weeks from the egg reaches a size often larger than that of the fully matured insect. (See Fig. 8.) At this time it ceases feeding and falls to the ground. We have observed but few deliberately walking down the tree. Each individual goes into the ground separately, entering by some crack or worm hole, and having reached a secure depth it hollows out for itself a little cell, and in this chamber it remains 
quiescent until the following year. Thrips get down into the ground from three to ten inches, ac'(ording to the structure and condition of the-soil; the prevailing depth is four to five inches. They are scattered generally from a few inches to several feet from the trunk of the tree. At the present time (Soptember 30 th), though the insects have been in the ground several montls, they are still active if disturbed and do not show signs of wing formation, the first indication of the approaching nymph. Insects taken from the ground on August 28th still showed green matter (chlorophyll) within the digestive tract, presumably food taken in weveral months before but as yet undigested.

The pupal changes take place in the ground in the same cell where the larva has spent so much of its time. We have not determinerl how long this stage lasts.

Orchardists know the adult insect best. It is the adult which comes to our trees in countless numbers and which does the greatest injury to fruit buds and blossoms. The mature insect, having wings, flies up from the ground to the tree and, if it finds the tree in suitable con$=$ dition, at once begins to feed; but if it does not find the proper conditions, it moves on to other and better places. Thrips remain close during the day, either feeding or depositing eggs. They often leave the food-plants just before sundown, and it is especially at this time that they migrate from place to place. We have distinguished two modes of flight: a hovering and a migrating one. If the food-plant offers suitable food the insect comes out for a few minutes, hovers around and a little later settles back on the same or a nearby tree. There is, howerer, a distinctly migratory flight, when the insects in great numbers $\mathrm{fly}_{\mathrm{y}}$ for some distance, and in this way they are spread over a large area.

Adult thrips appeared in many orchards in alarming numbers on February 22d during the season of 1905, and in 1904 some two or three days carlier than this. Thrips continued to come out from the ground on through March and April and for a short time during May. On May 5th pupal forms were taken from the soil, and if, as we think, the insect is but single-brooded, all of the previous year's forms had not matured at this time.

\section{METHODS OF CONTROL.}

Natural Encmies. - The subject of natural enemies for the controlling of our insect pests is of prime importance. If the pear thrips has an effective natural enemy, what is it? And if it is not present here, where can it be found? Such questions come to us repeatedly. First of all we must know as much as possible about the life habits of the thrips itself, and this is what we have tried to present in this report. Up to the present time we have found several common predaceous insects feeding on thrips, but noue which are parasitic. Predaceous 
forms attack their prey externally and literally devour them, while parnsitic insects, which are considered perhaps the most important as check insects, must live for a time within the body of their host.

Our pear thrips, from the very nature of its habits, spending by far the greater part of its life concealed several inches beneath the surface of the ground, as has been shown, is very largely protected from ordinary predaceous or parasitic insects. It comes from the ground so suddenly and injures the trees so quickly that those of its enemies which we have found here can hardly prove an effective check.

The Raphidians, the commonest feeders on thrips in the Santa Clara Valley, are general predaceous insects, and feed rather on the younger stages of thrips than on the fully developed insects. For the complete control of the thrips pest, they do not appear early enough in the season. Raphidians are distinctly a Western form of insect, being found only in the far West and especially in California; they are unusually voracious, and besides killing almost any insect which happens in their way, they will attack and devour each other if confined together.

Ants were thought by some to do much good as an enemy to thrips. One gentleman brought in an ant with a thrips impaled in its jawsthe evidence complete. This matter we took up somewhat in detail. Four hundred ants were taken as they descended the trunk of a thripsinfested tree. Twelve carried something in their jaws; four of these objects were thrips. From the observations only one per cent (four out of four hundred) were actually killing thrips. It may be that others of these ants killed thrips, but did not carry them down the tree. It has been a common observation among orchardists that where ants were usually abundant thrips were not numerous.

spiders killed many thrips. Breeding-cages were placed in trees for determining various points in the life habits of thrips, and later almost invariably one or more spiders would be found within and most of the thrips gone.

The most effective natural enemy of thrips in the Eastern States is a bug, Triphleps insidiosus Say, as mentioned by Dr. Hinds; it feeds on both plants and insects, and at times may be quite as destructive as the thrips itself.

It was noticed by both myself and Mr. Budlong that often a tree would be thickly infested with young thrips and when these disappeared, supposedly going into the ground, only a few could be found; they seemed also to leave the tree before reaching full growth. We believe the explanation for this is that a fungous disease thinned out their number - to quite a large extent. This is borne out by the fact that some dead thrips were found whose bodies were penetrated by a fungus mycelium, and in one case small sporangia were seen on tiny stalks projecting from the body. It is possible that these insects were dead before being attacked by the fungus, and that after all the fungus was not parasitic. 
Spraying.-It has been stated with regard to killing thrips by means of various spray mixtures that whatever these mixtures are they must be thoroughly applied to do even fair service. We have learned from this year's experience that for this particular thrips spraying is a rery unsatisfactory means of control. The insect is haril to reach because of its manner of hiding in bud or blossom, and difficult to kill without injuring the tree with the spray mixture itself. Because of its hahits of leaving the ground, extending over a period of sereral weeks, and its habits of migrating, one might apply sprays and kill most of the insects on his trees and within a rery few days find an infestation as heavy as before. The injury, as we have seen, is so rapid and so fatal, taking but a few days (four or five) to ruin an entire orchard, that were we tn depend on sprays all work would necessarily have to be done in a comparatively short time and repeated often, and this of course is impracticable.

It does not seem neessary at this time to give in detail the results of the spraying experinent, which we carried on during the past season. Fourteen different formulas were tried, including various forms of soap washes and caustics, tobacco, sulphur, crude carbolic and creosote oils. The sprays were carefully prepared under the personal supervision of Mr. Budlong and myself, and applied with a Bean power outfit with the Bean Cyclone and Vermorel nozzles, under pressure of from 140 to 170 pounds. The results were rery unsatisfactory. Exposed thrips would be killed, but those within the blossoms or buds showed almost no signs of injury. New adults and also young thrips,-for the young continued emerging from the stems and leaves where the eggs had been deposited,-appeared on the sprayed trees within al clay or two after the washes were applied, and after four or five days the trees revealed almost as heavy an infestation of both young and mature thrips as there was before any spraying had been done. No one wash proved satisfactory, and apparently under the conditions none can. sprays will doubtless be tried again, but they can only lessen the number of thrips with little or no appreciable resultis, and some injury to the tree is alnost certain to follow.

Methods of Cultiration.-From the foregoing it might seem an almost hopeless task to check the thrips by either natural or artificial me:ns. The insect, as we have wem, spends the greater part of its life beneath the soil, and this is probably the best time to attack it. After the larva is fully grown, it leaver the food-plant and seeks a secluded place in the ground. On entering the ground it follows openings such as cracks, or holes made by other inserts or worms, and reaching a depth of from four to six inches, though often decper, it hollows ont a small cell on the side of the larger opening, and thus securing itself awaits further developments. 
We believe that if the ground be thoroughly plowed and cultivated during November, December, and January, or before the insects leave the ground, which they begin to do by the first of February, many of these young thrips would be killed or injured or so disturbed that but few would ever reach maturity.

Our present manner of cultivation is well adapted to give the thrips a long, undisturbed period of rest. During the late spring and early summer, when thrips are in the ground, we give the soil nothing but light cultivation, and as the insects are still in an active larval stage they seek another place of hiding, if disturbed. After this no cultivation is usually done until the last of February or March of the following year, by which time the insects have left the ground. While the plowing and cultivating method of control has not been thoroughly tried, we believe it gives more promise than any other yet suggested.

\section{SUMMARY.}

The insect is single-brooded. Adult females appear and begin to deposit eggs in February. After four days in the egg the young appear, feed for a time on the tree, then drop and enter the ground, where the greater part of the year is passed.

No effective natural enemies are yet known.

Owing to the insect's method of feeding, its habits of coming from the ground, extending over a period of several weeks, and its habits of migrating, sprays can be only partially effective, even where thoroughly applied.

We suggest winter plowing and cultivating, with careful working about the trees, so as to kill or injure the immature forms of thrips. This plowing must be done before the first of February, at which time the mature insects begin to come out from the ground. 


